\title{
Az innovációs ökoszisztéma menedzsment strukturális kihívásai - a szakirodalom tükrében
}

\author{
Horváth Klaudia Gabriella \\ Nemzeti Közszolgálati Egyetem
}

\begin{abstract}
A TANULMÁNY CÉLJA
Az innováció a fenntartható gazdasági fejlődés egyik fő mozgatórugója. Arra tekintettel azonban, hogy az innováció általánosságban drága és bizonytalan folyamat, a gazdasági szereplök különböző együttmüködéseket hoznak létre az innovációs tevékenység költségeinek és kockázatainak csökkentése érdekében. Ezen kooperációk egyik típusának tekinthetők az innovációs ökoszisztémák. Ezzel összefüggésben jelen tanulmány egyrészt bemutatja az innovációs ökoszisztéma, mint együttmüködési struktúra fogalmának tudományos szempontú értelemzési kereteit, másrészt körvonalazza az ökoszisztéma menedzsment alapvető strukturális kérdéseit.
\end{abstract}

\begin{abstract}
ALKALMAZOTT MÓDSZERTAN
A tanulmányban alkalmazott módszertan széleskörủ szakirodalomfeldolgozás. Mivel magyar nyelven kevés tudományos igényü publikáció foglalkozik az innovációs ökoszisztémák fent említett kérdésköreivel, a tanulmányban lefektetett elméleti keretek elsősorban a magyarországi ökoszisztéma menedzsment-gyakorlat empirikus vizsgálatának kiindulópontjaként szolgálnak.
\end{abstract}

\section{LEGFONTOSABB EREDMÉNYEK}

A tanulmány egyik fontos eredménye, hogy magyar nyelven, közérthető módon mutatja be az innovációs ökoszisztéma fogalom tudományos gyökereit és definícióját. A tanulmány másik eredménye, hogy széleskörü szakirodalmi szintézis alapján azonosítja az innovációs ökoszisztéma menedzsment strukturális kihívásait. Az öt legfontosabb kihívás a következő: a partneri kör megválasztásának, a működési struktúra kialakításának, az ökoszisztémát vezető személy kijelölésének, az alkalmazkodóképesség meglétének, valamint a formális és informális kapcsolatok egyensúlyának kérdése.

\section{GYAKORLATI JAVASLATOK}

Az innovációs ökoszisztéma kifejezés mind a tudományos, mind pedig az üzleti- és kormányzati döntéshozói körökben egyre elterjedtebb. Fontos ugyanakkor, hogy a fogalom pontos értelmezési keretei nehezen lehatárolhatók, éppen ezért lényeges, hogy a kifejezést mindig jól meghatározott összefüggésben használjuk. Az ökoszisztémák kialakítása és menedzselése számos stratégiai és strukturális kérdést vet fel, mivel az ökoszisztémás kooperáció alapvető működési elve a hatékony értékteremtés. Az ökoszisztémák eredményes müködtetéséhez így nélkülözhetetlen a tudatos ökoszisztéma menedzsment.

Kulcsszavak: innováció, innovációs ökoszisztéma, ökoszisztéma menedzsment, innovációs együttmüködés

Köszönetnyilvánitás: Jelen publikáció az Innovációs és Technológiai Minisztérium Kooperatív Doktori Program Doktori Hallgatói ösztöndíj Programjának a Nemzeti Kutatási, Fejlesztési és Innovációs Alapból finanszírozott szakmai Támogatásával készült.

DOI: 10.15170/MM.2021.55.03.06 


\section{BEVEZETÉS INTRODUCTION}

A fenntartható gazdasági fejlődésben egyre növekvő szerepe van a tudásnak és a tudással szorosan összefüggő innováció összetett jelenségének. Habár az innováció fogalmát a téma kutatói Schumpeterhez (1934) kötik, a kifejezés nagyon sokrétü, jelentéstartalma folyamatosan bővül. (Rekettye 2002) Az innováció nemzetközi konszenzuson alapuló értelmezését jelenleg az Oslo Kézikönyv 2018-as kiadása rögzíti, amely szerint az innováció „olyan új vagy továbbfejlesztett termék, szolgáltatás, üzleti folyamat, vagy ezek kombinációja, amely jelentősen különbözik a piaci szereplö korábbi termékeitől, szolgáltatásaitól vagy üzleti folyamataitól, továbbá a terméket a szereplö sikeresen piacra viszi, üzleti folyamat esetén pedig az új vagy továbbfejlesztett folyamatot sikeresen alkalmazza", (a szerző fordítása) (OECD/Eurostat 2018, 20). Fontos azonban, hogy az innováció egyrészt drága (kiemelten termékinnovációk esetében), másrészt pedig bizonytalan folyamat. Ennek oka, hogy az új termék vagy szolgáltatás kifejlesztése akár éveket is igénybe vehet, a piaci siker viszont nem borítékolható elöre.

Annak érdekében, hogy az innovációs tevékenységet végző gazdasági szereplők valamilyen mértékben csökkentsék az innováció fent említett költségeit és kockázatait, az 1980-as évektől kezdve - nem utolsó sorban a japán lean-gyártás sikerére válaszul - egyre elterjedtebbé vált a gazdasági szereplők közötti innovációs célú formális és informális együttmüködések kialakítása. (Ries 2011) A szemléletváltást a szakirodalomban Chesbrough (2003) a zárt innovációs modellről a nyílt innovációs modellre való áttérésként írta le. A nyílt innovációs modell lényege, hogy az innováció nem csupán egy vállalaton belül valósulhat meg, hanem azon kívül is, több szereplö bevonásával, együttmüködésével, mivel számos, a vállalat számára létfontosságú innovációt nem a vállalaton belül alkotnak meg. (Béza \& Kállay 2013) Arra tekintettel, hogy az innovációs együttmúködések, hálózatok pontos fogalmi keretei nehezen meghatározhatók, a szakirodalomban számos együttmúködési formával, típussal találkozhatunk (pl.: klaszter, ökoszisztéma). (de Faria et al. 2010)

Jelen tanulmány középpontjában a napjainkban mind a tudományos, mind pedig az üzleti- és kormányzati döntéshozói körökben elterjedt innovációs ökoszisztémák vizsgálata áll. A tanulmány két részre osztható. Először az innovációs ökoszisztéma fogalom tudományelméleti gyökerei és értel- mezési keretei kerülnek bemutatásra. A fogalom tudományos igényủ definiálása azért kulcsfontosságú, mert ahogyan arra Gobble (2014) is utal, az ökoszisztéma kifejezés napjainkban divatos hívószóként (buzzword) funkcionál, amely következtében számos tudományos munka, elemzés és stratégia használja a fogalmat, anélkül, hogy az olvasók pontosan tisztában lennének annak jelentésével. A tanulmány második részében az ökoszisztéma, mint struktúra menedzsmentjével kapcsolatos legfontosabb gyakorlati kihívásokat tekintem át. Mivel a korábban, magyar nyelven, az innovációs ökoszisztémák témájához kapcsolódó publikációk (Vasvári és tsai 2020, Kálmán 2019, Grünhut 2018, Hornyák \& Kruzslicz 2016) nem térnek ki a téma általam vizsgált aspektusaira, jelen tanulmány az elméleti szakemberek és gyakorlati döntéshozók számára is fontos tanulságokkal szolgálhat.

\section{AZ AZ INNOVÁCIÓS ÖKO- SZISZTÉMA? WHAT IS AN INNOVATION ECOSYSTEM?}

Az innovációs ökoszisztéma az innovációs együttmüködések egyik típusának tekinthető. Noha a fogalom pontos értelmezése a mai napig viták tárgyát képezi a szakirodalomban, az Európai Bizottság (2020) mellett számos nemzetközi szervezet és tanácsadó cég (WEF 2020; McKinsey \& Company 2021) a koronavírus utáni gazdasági helyreállítás egyik kulcsfontosságú elemeként hivatkozik az ökoszisztémák megerösítésére. A következőkben széleskörü szakirodalmi vizsgálat alapján röviden bemutatom az innovációs ökoszisztéma fogalom kialakulásának folyamatát és értelmezési kereteit. A szakirodalom vizsgálattal kapcsolatos tudománymetriai, módszertani kérdéseket Horváth (2021) tekinti át részletesen.

$\mathrm{Az}$ ökoszisztéma, mint szervezetrendszer fogalma először a természettudományok területén, az ökológia-kutatásokban jelent meg. Tansley (1935) értelmezésében, a biológiai ökoszisztéma adott térbeli vagy strukturális alapon összetartozó szereplők és környezetük közötti kapcsolatok komplex halmaza, amelynek elsődleges célja a fenntartható egyensúly állapotának megőrzése.

A kifejezést később Moore (1993) az üzleti ökoszisztéma fogalom megalkotásával vezette be nagy sikerrel az üzlet-és menedzsmenttudományok területére. Moore $(1993,1996)$ értelmezésében az üzleti ökoszisztéma olyan gazdasági/üzleti jellegü közösség, amelynek résztvevői, az egymással kölcsönhatásban álló szervezetek és egyének együtt 
fejlödnek annak érdekében, hogy a környezetükben tapasztalható külső és belső változásokhoz sikerrel alkalmazkodjanak, valamint a fogyasztóik, illetve a piac igényeit kielégítsék. Az üzleti ökoszisztéma kifejezés használatának elterjedésére nagy hatással volt Gawer \& Cusumano (2002) üzleti platform elmélete, amely kifejezetten a technológiai óriásokra (Cisco, Microsoft) értelmezte az ökoszisztéma fogalmát, illetve a már idézett Chesbrough (2003) nyílt innovációs modellje is. Iansiti \& Levien (2004) könyvében az üzleti ökoszisztémák fontos tulajdonságára világított rá: a vállalatot körülvevő ökoszisztéma nagymértékben meghatározza a cég saját teljesítményét, tehát minden szereplő osztozik adott ökoszisztéma sorsában, sok esetben saját piaci erejétől függetlenül.
Az innovációs ökoszisztéma, mint önálló fogalom első megjelenése Adner nevéhez köthető. Adner (2006) tanulmányában az üzleti és innovációs ökoszisztémák között még nem tett világos különbséget, viszont később már számos elismert szerző egyértelműen külön fogalomként kezdte értelmezni az üzleti és innovációs ökoszisztémákat, így például Adner \& Kapoor (2010), Zahra \& Nambisan (2012), Autio \& Thomas (2014), valamint Adner (2017). A két ökoszisztéma típus közötti legnagyobb különbség, hogy míg az üzleti ökoszisztéma elsősorban az együttmüködés nyújtotta hozzáadott értékből származó hasznok megszerzésére (value capture), egyszerüebben mondva optimalizálásra törekszik, addig az innovációs ökoszisztéma középpontjában az értékteremtés (value creation) áll. (Valkokari 2015) A két fogalom összehasonlítását az 1. táblázat mutatja be.

1. táblázat: Az üzleti és innovációs ökoszisztémák fogalmi összehasonlítása Table 1. A Conceptual Comparison of Business and Innovation Ecosystems

\begin{tabular}{|l|l|l|}
\hline \multicolumn{1}{|c|}{ Szempontok } & \multicolumn{1}{|c|}{ Üzleti ökoszisztéma } & \multicolumn{1}{|c|}{ Innovációs ökoszisztéma } \\
\hline szakirodalmi vonatkozás & Moore (1993) & Adner (2006) \\
\hline együttmüködés célja & $\begin{array}{l}\text { a közösen teremtett értékböl } \\
\text { származó haszonszerzés, opti- } \\
\text { malizálás (value capture) }\end{array}$ & $\begin{array}{l}\text { új értékteremtés közösen (value } \\
\text { creation) }\end{array}$ \\
\hline résztvevők köre & $\begin{array}{l}\text { központi (irányító) vállalat, } \\
\text { beszállítók, fogyasztók }\end{array}$ & $\begin{array}{l}\text { vállalatok, felsőoktatási intéz- } \\
\text { mények, kutatóintézetek, civil } \\
\text { szféra (fogyasztók) }\end{array}$ \\
\hline $\begin{array}{l}\text { müködési mód, } \\
\text { koordináció }\end{array}$ & $\begin{array}{l}\text { jellemzően formális kapcsola- } \\
\text { tok, szerzödéses viszonyok }\end{array}$ & $\begin{array}{l}\text { a nagy kockázat miatt jó infor- } \\
\text { mális kapcsolatok nélkül nem } \\
\text { alakulnak ki a formális keretek }\end{array}$ \\
\hline jellemzó iparágak & $\begin{array}{l}\text { már müködő szektorok, ipará- } \\
\text { portok esetében (pl.: autóipar) }\end{array}$ & $\begin{array}{l}\text { általában új/még kiaknázatlan } \\
\text { szektorok esetében (pl.: tele- } \\
\text { kommunikáció, úrkutatás) }\end{array}$ \\
\hline
\end{tabular}

Forrás: Saját szerkesztés

Összefoglalóan innovációs ökoszisztéma fogalom alatt a következőket értjük: olyan szereplők, tevékenységek, eszközök, intézmények és az ezek között tudatosan alakitott kapcsolatok összessége, amelyek meghatározók egy gazdasági szereplö, vagy szereplök összességének innovációs teljesitménye és értékteremtö képessége szempontjából. (Granstrand \& Holgersson 2020)
A fenti fogalom meghatározásból (is) jól látszik, hogy a kifejezés pontos jelentéstartalma nehezen behatárolható. A kérdéskört tovább bonyolítja, hogy az üzleti és innovációs ökoszisztémák fogalma mellett a szakirodalomban találkozhatunk más ökoszisztéma kifejezésekkel is (pl. vállalkozói ökoszisztéma, szolgáltatási ökoszisztéma). Az egyes ökoszisztéma típusokra jelen tanulmány 
keretein belül nem térek ki, azonban a témáról bővebben ír Valkokari (2015), Gomes et al. (2018) és Jacobides et al. (2018).

Összességében levonható az a következtetés, hogy az innovációs ökoszisztémák megkülönböztető jellemzője más ökoszisztéma típusoktól, hogy az együttmüködés középpontjában az innovációs tevékenység elősegítése (value creation) áll. Arra tekintettel, hogy a fenntartható gazdasági fejlődés egyik kulcsa az új értékteremtés, az innováció pedig költséges és kockázatos folyamat, minden gazdasági szereplőnek egyaránt érdeke az innovációs együttmüködésekben, ökoszisztémákban való részvétel, illetve azok hatékony (meg)szervezése. Ezzel összefüggésben a tanulmány második felében a szakirodalomban az ökoszisztéma menedzsment témájában leggyakrabban felmerülö kihívásokat mutatom be.

\section{AZ ÖKOSZISZTÉMA MENEDZS- MENT STRUKTURÁLIS KIHÍVÁ- \\ SAI \\ STRUCTURAL CHALLANGES OF ECOSYSTEM MANAGEMENT}

Számos külföldi és magyar szerző foglalkozik az innováció menedzsment témakörével, annak elméleti és gyakorlati szempontjaival egyaránt (Powell et al. 1996, Tidd \& Bessant 2018, Buzás 2007, Borgulya \& Kovács 2020). Általánosságban innováció menedzsment alatt a szervezet innovációs kapaci- tásainak mozgósítását, a transzformációs képességek irányítását, valamint az egész innovációs folyamat vezérlését értjük. (Sára és tsai 2014, 43) Ezzel összefüggésben az innovációs ökoszisztéma menedzsment az innováció menedzsment egy részterületének tekinthető.

Adner $(2012,2017)$ munkái alapján a fogalom kétféle módon közelíthető meg: az ökoszisztéma menedzsment egyrészt vizsgálható az ökoszisztémában résztvevő szervezet(ek) szempontjából (ökoszisztéma stratégia), másrészt pedig, értelmezhető egyfajta müködési keretrendszerként (ökoszisztéma struktúra). A két megközelítést az 1. ábra mutatja be.

Az ökoszisztéma, mint stratégia olyan folyamatok és eszközök összessége, amelyek segítségével egy szervezet kialakítja és fenntartja a kapcsolatot az ökoszisztéma más résztvevőivel, miközben tudatosan alakítja saját pozícióját és értékteremtési lehetőségeit az ökoszisztémában. Ezzel szemben az ökoszisztéma, mint struktúra az ökoszisztémában résztvevő szervezetek közötti koherenciát, összhangot fenntartó képességek, folyamatok és eszközök összességét jelenti. (Adner 2017, Pellikka \& Ali-Vehmas 2016, Visscher et al. 2021) A két definícióból látható, hogy míg stratégiai szempontból a szervezetek ökoszisztémában betöltött önálló szerepe a hangsúlyos, addig strukturális szempontból a résztvevők közötti együttmüködést biztosító koherencia, összetartó erő és szervezetrendszer állnak a vizsgálat középpontjában.

\section{1. ábra: Az innovációs ökoszisztéma menedzsment fogalmának megközelítése Adner nyomán Figure 1. Adner's Theoretical Approach of Innovation Ecosystem Management}

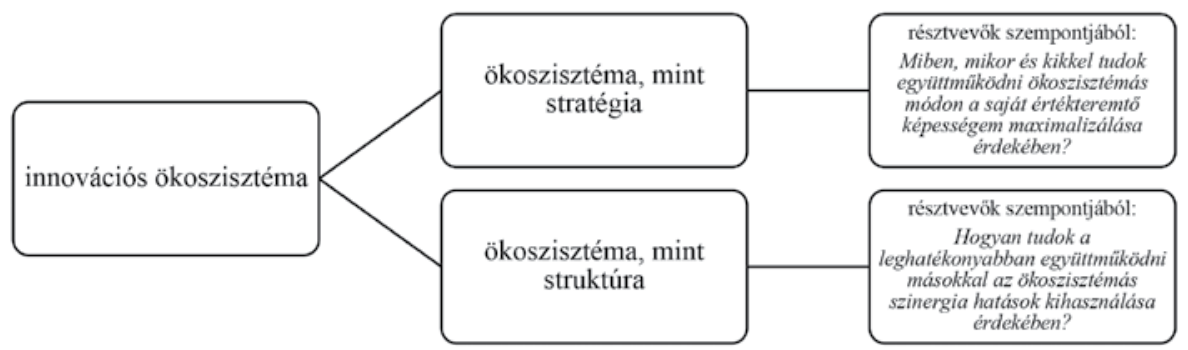

Forrás: Adner (2017) alapján saját szerkesztés 
Jelen tanulmányban az ökoszisztéma menedzsment témáját strukturális szempontból vizsgálom, így az innovációs ökoszisztéma, mint (nem feltétlenül intézményesített) szervezetrendszer áll az elemzés középpontjában.

$\mathrm{Az}$ ökoszisztémás kooperációk gyakorlati müködését tekintve a széleskörü szakirodalom feldolgozás alapján az alábbi öt kihívás azonosítható:

1. a partneri kör megválasztásának;

2. a müködési struktúra kialakításának;

3. az ökoszisztémát vezető személy kijelölésének;

4. az alkalmazkodóképesség meglétének, valamint

5. a formális és informális kapcsolatok egyensúlyának kérdése.

A továbbiakban az ökoszisztéma struktúra menedzsmentjének fent megjelölt, öt legfontosabb kihívásának elméleti összefüggéseit mutatom be.

\section{Partneri kör megválasztása Choosing Partners}

Mivel minden ökoszisztéma alapja az együttmüködés, egy ökoszisztéma kialakítása, vagy meglévő ökoszisztémába való belépés előtt minden résztvevő számára alapvető kérdés a partneri kör meghatározása. Különösen fontos ez abból a szempontból, hogy az innovációs ökoszisztémák sajátossága, hogy a résztvevők köre rendszerint nagyon heterogén. Mindez magában hordozza annak a lehetőségét, hogy az ökoszisztémában résztvevők a piacon egymás versenytársai is lehetnek, így a szervezeteknek el kell tudniuk határolni a kompetitív és kooperatív természetủ kapcsolataikat olyan módon, hogy egyik ne zárja ki a másikat. (Adner 2012) Versenytársak általában akkor vesznek részt azonos ökoszisztémában, ha az innovációs cél konkrét és objektív. Ebben az esetben a felek elsősorban az innovációval járó költségeket és kockázatokat osztják meg, mivel felismerik, hogy adott újdonság piacra viteléhez széleskörü technológiai fejlesztésre és ezek egy idejü alkalmazására van szükség.

Az ökoszisztémák partneri körére jellemzó továbbá a szervezeti és gondolkodásmódbeli sokféleség, amely nagymértékben ösztönzi a tanulási és innovációs folyamatokat. Éppen ezért a jól mủködő ökoszisztémák alapvető jellemzője, hogy a résztvevők különböző, de egymást kiegészítő erőforrásokkal és képességekkel rendelkeznek, amelyek kombinációja alapozza meg az ökoszisztéma innovációs lehetőségeit. Az ökoszisztéma résztvevőinek megválasztásánál, illetve új résztvevők befogadása előtt érdemes tehát az adott szervezet korábbi ered- ményei helyett annak a jövőbeli, esetleg a jelenben még kihasználatlan potenciálját figyelembe venni. (Dodgson 2007)

\section{A müködési struktúra kialakítása Estabilishing The Ecosystem's Structure}

Lényegében az innovációs ökoszisztémák kialakításának elengedhetetlen feltétele egyrészről az, hogy a résztvevők különféle, de magas színvonalú (vagy egyedi) pénzügyi, tárgyi és/vagy humán erőforrásokkal, kompetenciákkal rendelkezzenek, másrészt pedig az, hogy világosan azonosítsák az együttmüködés alapjául szolgáló közös érdekeket, másképpen fogalmazva az önálló érdekek keresztmetszetét. Mindez azonban csak megalapozza az ökoszisztémákat, a hosszú távú és sikeres müködéshez elemi kérdés az ökoszisztéma tudatos és szakmai menedzsmentje. Amennyiben a piaci szereplök az ökoszisztémás szervezet struktúráját nem megfelelően alakítják ki, úgy fennáll a veszélye annak, hogy az erőforrásokat pazarlóan használják fel, ami pedig hosszú távon az ökoszisztéma felbomlását vonja maga után, tekintve a résztvevők egyre kevesebb hasznot realizálhatnak az együttmüködés fenntartásából. (Ritala et al, 2013)

Az ökoszisztémák müködési struktúrája alapján Jacobides et al (2018) megkülönböztet nyílt és zárt ökoszisztémás rendszereket - Chesbrough (2003) innovációs modelljeihez hasonlóan. A nyílt ökoszisztémát a bizalmi kapcsolatok és hosszú távú elköteleződés, valamint a résztvevők körének gyakori változása jellemi. A zárt ökoszisztéma ezzel szemben szerződéses viszonyokon alapszik, a bizalom kevésbé kialakult. A nyílt ökoszisztémában tehát a játékszabályokat de facto módon, közmegegyezéssel alakítják ki a résztvevők, míg a zárt ökoszisztémában de jure, általában írásban foglalt szabályrendszer rögzíti a rendszer működési kereteit. Mindebböl az is következik, hogy a zárt ökoszisztémák nehezebben alkalmazkodnak a külső-belső változásokhoz és magasabbak a külső szereplök belépési költségei, ellenben a nyílt ökoszisztémás rendszerek kevésbé alkalmasak sok szereplő koordinálására.

Összességében tehát az ökoszisztémás együttmúködések müködési struktúrája klasszikus értelemben véve nem kötött. Elsősorban az ökoszisztéma létrehozásának céljától és a kapcsolódó iparágak alapvető jellemzőitől függ, hogy az ökoszisztéma inkább zárt vagy nyitott struktúrát vesz fel. Habár a szakirodalom (Jacobides et al. 2013, Rabelo \& Bernus 2015, Mantovini \& Ruiz-Aliseda 2016) alátámasztja, hogy a két struktúra dinami- 
kusan átjárható, a nyitott modellhez magas szintü bizalom kialakítása szükséges, amelyre a későbbiekben még kitérek.

\section{Az ökoszisztéma vezetőjének személye Appointment of The Ecosystem Leader}

A vezető, közvetítő szereplőre a szakirodalomban a leggyakrabban a határkulcsként/határörként (boundary spanner/gateekeper) tudás brókerként (knowledge broker) vagy szervezet esetén hibrid autonóm szervezetként (hybrid autonomous organizaton) hivatkoznak. (Tushman \& Scanlan 1981, Hargadon \& Sutton 1997, Tamtik 2018)

A közvetítő, vagy ökoszisztéma vezető szerepe hasonlóan a hagyományos projektmenedzsmenthez kettős. Egyrészről feladata, hogy a résztvevők eltérő igényei között konszenzust keressen, másrészről felel a közös célok teljesítéséhez szükséges feladatok elvégzésért és az erőforrások hatékony felhasználásáért. A közvetítő szereplő lehet személy vagy szervezet, illetve lehet az együttmüködés tagja, vagy azon kívül álló személy. Fontos kritérium ugyanakkor a közvetítővel szemben, hogy legyen pártatlan és politikailag független, valamint legyen szoros kapcsolatban minden résztvevő képviselőjével. (Tamtik 2018) A közvetítő kiválasztásánál fontos, hogy a személy vagy szervezet az ökoszisztéma valamennyi résztvevője számára hiteles legyen, tehát megfelelő szakmai képesítéssel és gyakorlati tapasztalattal rendelkezzen. Emellett lényeges, hogy a vezető elsősorban konszenzus és ne kompromisszum kialakítására törekedjen. Ennek oka, hogy ha a közvetítő túlságosan is „diplomata”, tehát a közös cél rovására próbálja figyelembe venni az egyéni érdekeket, azzal hosszú távon kiüresíti az együttmüködést. (Powell et al. 1996, Frølund \& Ziethen 2016)

A fentiekből jól látszik, hogy habár az ökoszisztéma vezetőjének kiválasztásához található néhány általános megállapítás a szakirodalomban, valójában minden ökoszisztémánál a résztvevők igényeihez kell alkalmazkodni az ökoszisztéma menedzsmentjének kialakítása során. Röviden az ökoszisztéma vezetője az, akit a partnerek a képességei alapján annak tekintenek. A világos szervezetrendszernél tehát fontosabb egy hiteles, az ökoszisztéma „karmestereként” funkcionáló személy vagy szervezet megléte.

\section{Alkalmazkodás és dinamikus képességek Adaptability and Dynamic Capabilities}

Ahogyan arra már a Bevezetésben is utaltam, az innovációs tevékenység számos bizonytalanságot hordoz magában. Az esetleges kudarc nem minden esetben a résztvevők közötti együttmüködés kudarca, hiszen a makro és mikro gazdasági környezet is egyaránt nagyon gyorsan változhat. A résztvevőket tehát külső és az ökoszisztémán belüli változások egyaránt érhetik, ráadásul beszélhetünk aszimmetrikus sokkokról is, amikor az ökoszisztéma tagjait eltérő mértékben érinti a pozitív vagy negatív irányú változás. (Pyka \& Nelson 2018)

Annak érdekében, hogy az ökoszisztémás szervezet ellenálló legyen a fent említett változásoknak, válságoknak, kiemelten fontos az alkalmazkodási képesség megléte. Alkalmazkodási képességnek nevezzünk azon attitüdök, ismeretek és készségek összességét, amelyek segítségével egy szervezet bizonytalan környezetben is müködni képes. Az alkalmazkodóképességet elsősorban a szervezeten belüli viselkedési bizonytalanság mértéke és a környezeti változások előrejelzésének lehetősége határozza meg. (Mason 2007)

$\mathrm{Az}$ alkalmazkodási képességek kifejezetten innovációs szempontból vizsgált fogalmi területe a Teece (2007) által megalkotott dinamikus képességek. Dinamikus képességek alatt - szorosan kötődve az alkalmazkodóképesség fogalmához - azokat a szervezet által tudatosan menedzselt és fejlesztett készségeket, képességeket értjük, amelyek lehetővé teszik a szervezet meglévő (tárgyi, szellemi, pénzügyi) erőforrásainak újra szervezését a külső környezet célzott befolyásolása, vagy a külső környezetben bekövetkezett változáshoz való alkalmazkodás érdekében. A két fogalom összehasonlításakor jól látható, hogy míg alkalmazkodás alatt inkább egy passzív folyamatot értünk, addig a dinamikus képességek lényege, hogy a szervezet maga is aktív szerepet játszik a külső környezet valamilyen mértékü - befolyásolásában.

Mivel az innovációs ökoszisztémákban a partnerek elsődleges célkitüzése az új értékteremtés, a fentiek alapján elengedhetetlen, hogy az ökoszisztémás szervezet jó alkalmazkodó képességgel és folyamatosan fejlesztett dinamikus képességekkel rendelkezzen. Ehhez azonban alapvető feltétel a bizalom, valamint az erős és gyenge kapcsolatok megléte, amelyre a következő alfejezetben térek ki részletesen. 


\section{Aformális és informális kapcsolatok egyensúlya, a bizalom fontossága The Equilibria of Formal and Informal Ties, The Importance of Trust}

Ahhoz, hogy egy ökoszisztéma hatékonyan müködhessen, ezáltal pedig, mint szervezet, dinamikusan képes legyen alkalmazkodni a korábban említett külső és belső változásokhoz, elengedhetetlen a partnerek közötti bizalom megléte. Ahogyan Cobben \& Roijakkers (2018) fogalmaz: az ökoszisztéma kialakításának előfeltétele az érdekközösség, míg a müködtetés alapja a bizalom. A bizalom fogalmát Castaldo et al. (2010) tanulmánya alapján a következőképpen határozhatjuk meg: a bizalom egy szervezet vagy személy megbízhatóságával és képességeivel szemben támasztott jövőbeli, pozitív irányú elvárás, amelyet bizonytalan környezeti hatások sem befolyásolnak kedvezötlen irányba.

$\mathrm{Az}$ ökoszisztémás együttműködésekben a bizalom megléte két dolgot jelöl egyszerre. Egyrészt jelenti a jóhiszeműséget tehát azt a feltételezést, hogy a többi partnernek is érdeke az ökoszisztéma leghatékonyabb múködtetése és fejlesztése. Másrészt beszélhetünk kompetencia alapú bizalomról, amely az ökoszisztéma többi résztvevőjének a hozzáértésébe, szakértelmébe vetett hitet jelenti. Összefoglalóan tehát az ökoszisztéma szereplőinek egyszerre kell bíznia abban, hogy a partnereik teljesítik a rájuk háruló feladatokat és abban, hogy ezek teljesítésére valóban megvannak az erőforrásaik.

A bizalom alapját a személyek és szervezetek közötti kapcsolatok jelentik, hiszen a bizalmat a racionális érdekek (mikor a partnernek nem érdeke félrevezetni bennünket) mellett, a személyes ismeretség befolyásolja leginkább.

Granovetter (1973) tanulmányában mutat rá arra, hogy az együttmüködéseket erös és gyenge kapcsolatok alkotják. Az erős kapcsolatok jellemzője, hogy a felek általában hivatalos - gyakran szerződésben rögzített - úton kommunikálnak, az információmegosztásban pedig csak a legszükségesebbekre szorítkoznak. Ezzel szemben a gyenge kapcsolatok sajátossága a partnerek közötti informális, esetleg régre visszanyúló ismeretség, ezzel együtt pedig a rendelkezésre álló információk, személyes vélemény könnyebb átadása, egyfajta közös gondolkodás keretében.

Lényeges, hogy az erős és gyenge kapcsolatok nem egymással ellentétes, hanem egymást kiegészítő tényezői a bizalomnak. Blomqvist \& Levy (2006) tanulmányában arra mutat rá, hogy az erős kapcsolatok általában fragmentálnak (mi és ők elkülönülése), tehát meghúzzák az együttmü- ködés világos határait, míg a gyenge kapcsolatok integrálnak, mert olyan szervezetek és személyek együttmüködését teszik lehetővé, akik egyébként kevéssé kooperálnának. Mivel azonban az innováció bizonytalan folyamat, egyértelmü, hogy az innovációs ökoszisztémában mind az erős, mind pedig a gyenge kapcsolatok kulcsfontosságúak. A túl nagy mértékü bizalom azonban az innovációs szándék ellaposodásához vezet, tehát az egészséges rivalizálás minden ökoszisztémában kulcsfontosságú, azonban a személyes ellentétek könnyen szétfeszíthetik az együttmüködés kereteit. A lényeg tehát az, hogy az ökoszisztéma tagjai egészséges egyensúlyt tartsanak fent a formális és informális kapcsolatok között. Így például a partnerek közötti személyes jó viszony ne visszaélésekhez, szélsőséges esetben korrupciós tevékenységhez vezessen, hanem az ökoszisztéma egészének a javát szolgálja. (de Clercq et al. 2009)

\section{ÖSSZEFOGLALÁS SUMMARY}

A tanulmányban bemutattam az innovációs ökoszisztémák fogalmi kereteit majd azonosítottam az ökoszisztémában, mint együttmüködési struktúrában rejlö legfontosabb vezetés-és szervezetelméleti kihívásokat.

$\mathrm{Az}$ innovációs ökoszisztémák témája mind a tudományos, mind pedig a kormányzati-és vállalati döntéshozói körökben egyre népszerübb, noha a fogalom pontos jelentése továbbra is bizonytalan. A tanulmányban a Granstrand \& Holgersson (2020) friss munkájában megfogalmazott definíciót tekintettem irányadónak, amely nagyon tág jelentéstartalommal társítja az innovációs ökoszisztémák fogalmát. A szerzőpáros lényegében minden, az adott szervezet innovációs és értékteremtő képessége szempontjából fontos tényezőt az ökoszisztéma részének tekinti.

Az innovációs ökoszisztémákat elsősorban az különbözteti meg egyéb, innovációs célú együttmüködésektől, hogy az ökoszisztémás kooperáció célja minden esetben az új értékteremtés (value creation), nem pedig az operacionalizálás. Emellett az ökoszisztémákban a hangsúly a résztvevőkön és a közöttük lévő kapcsolatokon van, míg az innovációs rendszereknél inkább az intézményi környezet és a rendelkezésre álló erőforrások, ismeretek állnak a vizsgálat középpontjában. (Weber \& Truffer, 2017)

Mivel az ökoszisztémák esetében rendszerint nem beszélhetünk kötött szervezeti keretekről, kiemelten fontos az ökoszisztéma hatékony 
menedzsmentje. Ezzel összefüggésben a tanulmány második felében bemutattam az innovációs ökoszisztémák öt legfontosabb strukturális jellegü vezetés-és szervezetelméleti kihívását. Az elemzés eredményeit a 2. táblázat foglalja össze.

\section{2. táblázat: Az ökoszisztéma menedzsment legfontosabb strukturális kihívásai Table 2. The Main Challanges of Ecosystem Management}

\begin{tabular}{|c|c|}
\hline $\begin{array}{c}\text { Strukturális kihívások az } \\
\text { ökoszisztéma menedzs- } \\
\text { mentben }\end{array}$ & Az ökoszisztéma menedzsment strukturális jellemzői \\
\hline Partneri kör megválasztása & $\begin{array}{l}\text { - A résztvevőket elsősorban ne azok korábbi eredményei, hanem a } \\
\text { jövőbeli potenciálja alapján válasszuk ki. } \\
\text { - Versenytársak együttmüködése esetén az innovációs cél legyen vilá- } \\
\text { gos és objektív. }\end{array}$ \\
\hline $\begin{array}{c}\text { Működési struktúra kiala- } \\
\text { kítása }\end{array}$ & $\begin{array}{l}\text { - Zárt ökoszisztémás modell jellemzői: szerződéses viszonyok, biza- } \\
\text { lom alacsony foka, feladatorientált, több szereplő koordinálására is } \\
\text { alkalmas. } \\
\text { Nyílt ökoszisztémás modell jellemzői: informális kapcsolatok nagy } \\
\text { száma, bizalom magas foka, kapcsolatorientált, sok szereplő koor- } \\
\text { dinálására nem alkalmas. }\end{array}$ \\
\hline $\begin{array}{l}\text { Ökoszisztéma vezető sze- } \\
\text { mély/szervezet kijelölése }\end{array}$ & $\begin{array}{l}\text { - } \quad \text { Az ökoszisztéma vezetője lehet személy vagy szervezet. } \\
\text { - Lényeges jellemzök: függetlenség, pártatlanság, magas szintű szak- } \\
\text { értelem, érdekek hiteles képviselete, konszenzus kereső és kapcso- } \\
\text { latépítő magatartás. }\end{array}$ \\
\hline $\begin{array}{c}\text { Alkalmazkodóképességek } \\
\text { és dinamikus képességek } \\
\text { fejlesztése }\end{array}$ & $\begin{array}{l}\text { - A szereplők saját alkalmazkodóképességének összessége nem } \\
\text { egyenlő az ökoszisztéma, mint szervezetrendszer alkalmazkodóké- } \\
\text { pességével. } \\
\text { Az ökoszisztéma, mint szervezet dinamikus képességeinek folya- } \\
\text { matos fejlesztése elengedhetetlen a külső és belső változásokhoz } \\
\text { való gyors alkalmazkodás érdekében. }\end{array}$ \\
\hline $\begin{array}{l}\text { Formális és informális } \\
\text { kapcsolatok egyensúlya }\end{array}$ & $\begin{array}{l}\text { - A bizalom kettős szerepe: jóhiszemüség és kompetencia alapú biza- } \\
\text { - } \quad \text { Az. } \\
\text { tok peős kapcsolatok jellemzően fragmentálnak, a gyenge kapcsola- } \\
\text { mális kapcsolatok egyensuálya szükséges. } \\
\text { - A túlzott bizalom az innovációs tevékenység ellaposodásához vezet, } \\
\text { igy a résztvevők közötti egészséges verseny megtartása kulcsfon- } \\
\text { tosságú. }\end{array}$ \\
\hline
\end{tabular}

Forrás: Saját szerkesztés

A tanulmány eredményei széleskörü szakirodalom feldolgozáson alapulnak, ezért fontos kiemelni, hogy a vizsgálat célja a hatékony ökoszisztéma menedzsment strukturális kihívásainak elméleti megalapozása volt. Ezzel összefüggésben a tanulmány alapvető korlátja, hogy saját vizsgálati eredmények még nem állnak rendelkezésre a magyarországi tapasztalatokat illetően. A tanulmányban lefektetett elméleti keretek így elsősorban a magyarországi ökoszisztéma menedzsment-gya- korlat empirikus vizsgálatának kiindulópontjaként szolgálnak. Arra tekintettel, hogy magyar nyelven az innovációs ökoszisztémák témájában szintetizáló jellegű munka nem jelent meg korábban, a tanulmány ismeretterjesztő és gondolatébresztő jellege révén a gyakorlati döntéshozók számára is fontos tanulságokkal szolgálhat. 


\section{HIVATKOZÁSOK REFERENCES}

Adner, R. \& Kapoor, R. (2010), „Value Creation in Innovation Ecosystems: How The Structure of Technological Interdependence affects Firm Performance in New Technology Generations", Strategic Management Journal, 31(3), 306333. DOI: doi.org/10.1002/smj.821

Adner, R. (2006), ,Match Your Innovation Strategy to Your Innovation Ecosystem", Harvard Business Review, 34(4), 98-107.

Adner, R. (2012), Wide Lens - a New Strategy for Innovation, London: Portfolio Penguin.

Adner, R. (2017), „Ecosystem as Structure: An Actionable Construct for Strategy", Journal of Management, 43(1), 39-58. DOI: $10.1177 / 0149206316678451$

Autio, E. \& Thomas, L. D. W. (2014), Innovation Ecosystems - Implications for Innovation Management, in: Dodgson, M., Gann, D. M. \& Philips, N. (eds) The Oxford Handbook of Innovation Management, Oxford: Oxford University Press, 204-228. DOI: 10.1093/oxfor $\mathrm{dhb} / 9780199694945.001 .0001$

Béza D. - Kállay L. (2013), „A nyitott innováció szerepe a gazdasági felzárkózásban”, Külgazdaság, 57(9-10), 38-53.

Blomqvist, K. \& Levy, J. (2006), „Collaboration Capability - A Focal Concept in Knowledge Creation and Collaborative Innovation in Networks", International Journal of Management Concepts and Philosophy, 2(1), 31-48. DOI: 10.1504/IJMCP.2006.009645

Borgulya Á. - Kovács É. (2020), „A vállalaton belüli innováció-kommunikáció, mint a szervezeti kultúra része - a szakirodalom tükrében", Marketing \& Menedzsment, 54(4), 63-75. DOI: 10.15170/MM.2020.54.04.05.

Buzás N. (2007), Innovációmenedzsment a gyakorlatban, Budapest: Akadémiai Kiadó.

Castaldo, S., Premazzi, K. \& Zerbini, F. (2010), „The Meaning(s) of Trust. A Content Analysis on The Diverse Conceptualizations of Trust in Scholarly Research on Business Relationships", Journal of Business Ethics, 96(4), 657-668. DOI: $10.1007 / \mathrm{s} 10551-010-0491-4$

Chesbrough, H. (2003), Open Innovation: The New Imperative for Creating and Profiting from Technology, Boston: Harvard Business School Publishing Corporation.

Cobben, D. \& Roijakkers, N. (2018), „The Dynamics of Trust and Control in Innovation Ecosystems", International Journal of Innovation, 7(1), 1-25. DOI: 10.5585/iji.v7i1.

de Clercq, D., Thongpapanl, N. \& Dimon, D. (2009), „When Good Conflict Gets Better and Bad Conflict Becomes Worse: The Role of
Social Capital in The Conflict-Innovation Relationship", Journal of The Academy of Marketing Science, 37(3), 283-297. DOI: 10.1007/ s11747-008-0122-0

de Faria, P., Lima, F. \& Santos, R. (2010), „Cooperation in Innovation Activities: The Importance of Partners", Research Policy, 39(8), 10821092. DOI: $10.1016 /$ j.respol.2010.05.003

Dodgson, M. (2007), Technological Collaboration, in: Hanusch, H. \& Pyka, A. (eds) Companion to Neo-Schumpeterian Economics, 193-200 Cheltenham: Edward Elgar. DOI: $10.4337 / 9781847207012$

Frølund, L. \& Ziethen, M. (2016), „The Wisdom of The Intermediary: The Role, Function, and Ways-of-being of The Intermediary in a Strategic Program for University-Industry Relations", Triple Helix Journal, 3(9), 1-21. DOI: 10.1186/ s40604-016-0039-4

Gawer, A. \& Cusumano, M. A. (2002), Platform Leadership: How Intel, Microsoft and Cisco Drive Industry Innovation, Boston: Harvard Business School Press.

Gobble, M. MaryAnne (2014), „Charting the Innovation Ecosystem", Research Technology Management, 57 (4), 55-59. DOI: 10.5437/08956308X5704005

Gomes, V. de L. A., Facin, A. L. F., Salerno, M. S. \& Ikenami, R. K. (2018), „Unpacking The Innovation Ecosystem Construct: Evolution, Gaps and Trends", Technological Forecasting \& Social Change, 136(11), 30-48. DOI: 10.1016/j.techfore.2016.11.009

Granovetter, M. (1973), „The Strength of Weak Ties", American Journal of Sociology, 78(6), 1360-1390.

Granstrand, O. \& Holgersson, M. (2020), „Innovation ecosystems: A Conceptual Review and A New Definition", Technovation, 90-91(February-March), 1-12. DOI: 10.1016/j.technovation.2019.102098

Grünhut Z. (2018), „Innovációs ökoszisztéma társadalomelméleti kontextusban", Tudásmenedzsment, 19(2), 33-45.

Hargadon, A. \& Sutton, R. I. (1997), „Technology Brokering and Innovation in a Product Development Firm", Administrative Science Quarterly, 42.(4), 716-749. DOI: 10.2307/2393655

Hornyák M. - Kruzslicz F. (2016), „Egyetemi ökoszisztéma vizsgálata big data környezetben", Marketing \& Menedzsment, 50(3-4), 19-32.

Horváth K. (2021), „Az innovációs ökoszisztéma-kutatások növekvő fontossága - a téma tudománymetriai elemzése", Köz-gazdaság, 16(3), megjelenés alatt.

Iansiti, M. \& Levien, R. (2004), The Keystone Advantage. What the New Dynamics of Business Ecosystems Mean for Strategy, Innovation, 
and Sustainability, Boston: Harvard Business School Press.

Jacobides, G. M., Cennamo, C. \& Gawer, A. (2018), „Towards a Theory of Ecosystems”, Strategic Management Journal, 39(8), 2255-2276. DOI: 10.1002/smj.2904

Kálmán A. (2019), „A regionális ökoszisztéma és az egyetemek szerepe az innovációs folyamatban”, Iskolakultúra, 9(29), 51-68. DOI: 10.14232/ISKKULT.2019.9.51

Mantovani, A. \& Ruiz-Aliseda, F. (2016), „Equilibrium Innovation Ecosystems: The Dark Side of Collaborating with Complementors", Management Science, 62(2), 1-16. DOI: 10.1287/ mnsc. 2014.2140

Mason, R., B. (2007), ,The External Environment's Effect on Management and Strategy: A Complexity Theory Approach", Management Decision, 45(1), 10-28.

Moore, J. F. (1993), „Predators and Prey: A New Ecology of Competition", Harvard Business Review, 71(3), 75-86.

Moore, J. F. (1996), The Death of Competition: Leadership and Strategy in The Age of Business Eosystems, New York: HarperBusiness.

Pellikka, J. \& Ali-Vehmas, T. (2016), „Managing Innovation Ecosystems to Create and Capture Value in ICT Industries", Technology Innovation Management Review, 6(10), 17-24. DOI 10.22215/timreview/1024

Powell, W., Koput, K. \& Smith-Doerr, L. (1996), „Interorganizational Collaboration and the Locus of Innovation: Networks of Learning in Biotechnology, Administrative Science Quarterly, 41(1) 114-145. DOI: 10.2307/2393988

Pyka, A. \& Nelson, R. R. (2018), Schumpeterian Competition and Industrial Dynamics, in: Nelson, R. R. (ed), Modern Evolutionary Economics, Cambridge: Cambridge University Press, 104-143. DOI: 10.1017/9781108661928

Rabelo, R. J. \& Bernus, P. (2015), „A Holistic Model of Building Innovation Ecosystems", IFAC PapersOnLine, 48(3), 2250-2257. DOI: 10.1016/j.ifacol.2015.06.423

Rekettye G. (2002), „Gondolatok az innováció értelmezéséről és törvényszerüségeiről”, Marketing \& Menedzsment, 36(1), 42-52.

Ries, E (2011), The Lean Startup: How Today's Entrepreneurs Use Continous Innovation to Create Radically Succesful Businesses, New York: Crown Business.

Ritala, P., Agouridas, V., Assimakopoulos, D. \& Gies, O. (2013), „Value Creation and Capture in Innovation Ecosystems: A Comparative Case Study", International Journal of Technology Management, 64(3/4), 244-267. DOI: 10.1504/ IJTM.2013.056900

Sára Z., Csedő Z., Fejes J., Tóth T. \& Pörzse G.
(2014), „Innovációmenedzsment és innovációs stratégiák", Vezetéstudomány, 45(10), 42-48.

Schumpeter, J. A. (1934), The Theory of Economic Development: An Inquiry into Profits, Capital, Credit, Interest, and the Business Cycle, New Jersey: Transaction Books, New Brunswick.

Tamtik, M. (2018), „Innovation Policy is A Team Sport - Insights From Non-Governmental Intermediaries in Canadian Innovation Ecosystem", Triple Helix Journal, 5(1), 1-19. DOI: 10.1186/ s40604-018-0062-8

Tansley, G. A. (1935), ,The Use and Abuse of Vegetational Concepts and Terms", Ecology, 16(3), 284-307. DOI: $10.2307 / 1930070$

Teece, D. J. (2007), „Explicating Dynamic Capabilities: The Nature and Microfoundations of (Sustainable) Enterprise Performance", Strategic Management Journal, 28(13), 1319-1350. DOI: $10.1002 / \mathrm{smj} .640$

Tidd, J. \& Bessant, J. (2018), „Innovation Management Challanges: From Fads to Fundamentals", International Journal of Innovation Management, 22(5), 1-13. DOI: 10.1142/ S1363919618400078

Tushman, M. L. \& Scanlan, T. J. (1981), „Boundary Spanning Individuals - Their Role in Information-transfer and Their Antecedents", The Academy of Management Journal, 24(2), 289-305.

Valkokari, K. (2015), „Business, Innovation, and Knowledge Ecosystems: How They Differ and How to Survive and Thrive within Them", Technology Innovation Management Review, 5(8), 17-24.

Vasvári B., Mayer G. \& Vasa L. (2020), „A tudományos és innovációs parkok szerepe a tudásgazdaság és az innovációs ökoszisztéma fejlesztésében", Tér-Gazdaság-Ember, 8(2), 95-107.

Visscher, K., Hahn, K. \& Konrad. K. (2021), „Innovation Ecosystem Strategies of Industrial Firms: A Multilayered Approach to Alignment and Strategic Positioning", Creativity and Innovation Management, 30(1), 1-13. DOI: 10.1111/ caim.12429

Weber, K. M. \& Truffer, B. (2017), „Moving Innovation Systems Research to The Next Level: Towards an Integrative Agenda", Oxford Review of Economic Policy, 33(81), 101 - 121. DOI: $10.1093 /$ oxrep/grx002

Zahra, S. A. \& Nambisan, S. (2012), „Entrepreneurship and Strategic Thinking in Business Ecosystems", Business Horizons, 55(3), 219 229. DOI: 10.1016/j.bushor.2011.12.004

Online források:

Online references:

Európai Bizottság (2020), A Robust Innovation Ecosystem for The Future of Europe, https:// 
op.europa.eu/en/publication-detail/-/publication/c7552948-f6fc-11ea-991b-01aa75ed71a1 (Utolsó letöltés: 2021. 07. 20.)

McKinsey \& Company (2021), Europe's Innovation Wunderkinds: The Rising B2B Start-Up Ecosystem, https://www.mckinsey.com/industries/technology-media-and-telecommunications/our-insights/europes-innovation-wunderkinds-the-rising-b2b-startup-ecosystem (Utolsó letöltés: 2021. 07. 20.)
OECD/Eurostat (2018), Oslo Manual 2018: Guidelines for Collecting, Reporting and Using Data on Innovation, The Measurement of Scientific, Technological and Innovation Activities, Paris, Luxembourg: OECD Publishing.

Word Economic Forum (WEF) (2020), The Global Competitiveness Report: How Countries are Performing on the Road to Recovery, https:// www.weforum.org/reports/the-global-competitiveness-report-2020 (Utolsó letöltés: 2021. 07. 20.)

Horváth Klaudia Gabriella, PhD hallgató Horvath.Klaudia.Gabriella@uni-nke.hu Nemzeti Közszolgálati Egyetem Közigazgatás-Tudományi Doktori Iskola

\section{Structural Challanges of Innovation Ecosystem Management - a Theoretical Approach}

\section{THE AIMS OF THE PAPER}

Innovation is one of the main drivers of sustainable economic development. Since innovation is an open ended and expensive process, market players particiapte in various collaborations to reduce the costs and risks of innovation activity. In this context, the study presents a scientific interpretation of the concept of innovation ecosystem as a collaborative structure, and outlines the basic structural challanges of ecosystem management.

\section{METHODOLOGY}

The study is based on extensive literature review. The theoretical framework in the study serves primarily as a starting point for the empirical research of ecosystem management practice in Hungary.

\section{MOST IMPORTANT RESULTS}

On the one hand the study summarizes the scientific origins and definition of the concept of innovation ecosystem. On the other hand, the study identifies the structural challenges of innovation ecosystem management based on a broad literature synthesis. The five main challenges are: choosing partners, estabilishing the ecosystem's strutcutre, appointment of the ecosystem leader, adaptability and dynamic capaibilites, the importance of trust.

\section{RECOMMENDATIONS}

Innovation ecosystem is functioning as a buzzword nowadays. The exact interpretation of the concept is difficult to define, which is why it is highly important to always use the notion in a clear context. Furthermore, the design and management of ecosystems raises a number of strategic and structural challanges, as the basic principle of these cooperations is effective value creation. Conscious ecosystem management is thus essential for the efficient and effective operation of ecosystems.

Keywords: innovation, innovation ecosystem, ecosystem management, innovation networks

Acknowledgements: This publication was prepared with the Professional Support of the Doctoral Student Scholarship Program of the Co-Operative Doctoral Program of the Ministry of Innovation and Technology financed from the National Research, Development and Innovation Fund. 